\title{
Amor est passio: a 15. századi német ajkú területek De amore-kéziratairól
}

\begin{abstract}
A De amore címü szerelmi értekezés a XII. században egyértelmüen francia közegben, Marie de Champagne udvarában, francia közönség számára készült, ugyanakkor latin nyelven. A szerelmi értekezés sem a XIII., sem a XIV. században nem tünik fel német területen, ám a XV. században teret hódít magának. Az elméleti értekezés jelenléte nemcsak nyomokban igazolható, épp ellenkezóleg, az évszázad elejétól a végéig jelen van, a lovagi-didaktikus költészetben jelentös helyet foglal el. Tanulmányomban a traktátus német ajkú területeken megfigyelhetö recepciótörténetét mutatom be az általam eddig feldolgozott kódexek alapján. ${ }^{1}$
\end{abstract}

Kulcsszavak: Andreas Capellanus, De amore, recepciótörténet, német ajkú területek

\section{A traktátus újrafelfedezése}

Andreas Capellanus De amore címü traktátusának számos, gyakran egymástól élesen eltérő véleményre helyezkedő értelmezője között egy dologban egyetértés mutatkozik: ez a mü a szerelem felfogását skolasztikus alapossággal és felépítéssel tárja elénk. ${ }^{2}$

A traktátus a XII. században egyértelmüen francia közegben, Marie de Champagne udvarában, francia közönség számára készült, ugyanakkor latin nyelven. Andreas Capellanus müve három könyvből áll: az első nagyjából a mű kétharmadát öleli fel, amelyben a szerző a szerelmet mint fogalmat definiálja, megvizsgálja annak eredetét, és azt, hogy

\footnotetext{
${ }^{1}$ A publikáció az MTA-SZTE Antikvitás és Reneszánsz: Források és Recepció Kutatócsoport (TK2016-126) támogatásával jelent meg.

2 KÖSZEGHY (2012: 280).
} 
kik között jöhet létre, hogyan és hányféleképpen. A második könyvben a megszerzett szerelem megőrzéséről beszél, illetve annak elmúlásáról, vagy épp ellenkezőleg, fokozódásáról. Leírja, miféle jelek utalnak arra, hogy az érzés letünőben van. Körüljárja a hütlenség kérdéskörét, majd felsorolja a szerelem királyától, Erósztól kapott harmincegy szabályt. Mindezzel szemben egyfajta pálfordulás jelenik meg a harmadik, egyben záró könyvben, amit már maga a cím is jelez: A szerelem visszautasításáról. Ebben, mintegy palinódiaként, úgy tünik, hogy a káplán teljességgel visszavonja addigi vélekedéseit, s már-már valóságos nőgyülölőként a szerelem káros hatásait taglalja.

A szakirodalom jelen állása szerint Gaston Paris volt az első, aki az udvari szerelem kodifikációjaként aposztrofálta a De amorét, ${ }^{3}$ ami minden bizonnyal hatással lehetett Emil Trojelre, aki nyolc évvel később elkészítette latinul az értekezés kritikai kiadását. ${ }^{4}$ Trojel az akkor ismert tizenkét fennmaradt kéziraton keresztül mutatta be, hogy a De amore a XII. századtól kezdve töretlen népszerüségnek örvendett. Ismertette a kéziratok provenienciáját, és amihez személyesen is hozzáfért, arról leíró katalógust is készített. A bevezetés után a három könyvből álló szerelmi értekezés szövegét, a jegyzetapparátusban pedig az egyes kéziratokban szereplő szövegvariánsokat mutatta be. Ugyanakkor némi pontosításra szorul a traktátus újbóli felfedezésének története: nem Gaston Paris volt az, aki annak 1614-es nyomtatott kiadása után elsőként említi meg a szerelmi traktátust, és nevezi meg azt az udvari szerelem müfajának alapműveként a XIX. században. Johann Christoph von Aretin kiváló német publicista, történész, könyvtáros és ügyvéd Aussprüche der Minnegerichte című monográfiájában hosszan idézi a káplán müvét, azon belül is a 21 szerelmi ítéletet, a Champagne grófnőjéhez írt levelet, és annak válaszát, valamint a breton lovag történetét és a 31 szerelmi szabályt. ${ }^{5}$ Von Aretin müncheni tartózkodása alkalmával vette kézbe Johannes Hartlieb munkáját, aki 1440-ben fordította le népnyelvre a traktátust. ${ }^{6}$ A XIX. század elején a német területeken sokkal inkább a népnyelvü kiadás volt a

\footnotetext{
3 PARIS (1888), PARIS (1884: 403-404), PARIS (1872: 105-107), KIM (2010: 589-606).

4 Trojel (1892).

${ }^{5}$ ARETIN (1803: 61-162).

${ }^{6}$ AREtin (1803: 3).
} 
meghatározó forrás az irodalomtörténészek számára, mint a latin nyelvü.

Hartlieb fordítása során az értekezés szerzőjét hibásan Albertano da Bresciával azonosítja Andreas Capellanus helyett. Albertano szintén a XII. század végén élt, ugyanakkor nem francia területen, hanem ÉszakItáliában. Nevéhez több sermo és traktátus köthető. Éppen ezért Von Aretin felveti a kérdést, hogy a traktátus eredetileg itáliai népnyelven vagy latinul íródott-e, ugyanakkor Albertano neve azt sejteti számára, hogy a kitűnő jogász azért írta meg latinul a szerelmi traktátust, mert akkoriban (XII. század vége) a vulgáris nyelv még igen kezdetleges volt. ${ }^{7}$ Aretin monográfiájában közli Hartlieb fordítását, valamint a rendelkezésére álló latin kézirat javításával együtt a traktátus fentebb említett részleteit, mindezt a XIX. századinak megfelelő német helyesírással. A könyv végén a nyomtatásba még nem került olasz nyelven írott részeket is beemeli, amelyeket a Vocabulario Della Cruscából vett át. ${ }^{8}$ A latin nyelvü kézirat forrásának beazonosítása nem tűnik nehéz feladatnak, hiszen megjegyzi, hogy a kézirat utolsó fejezetében azt olvashatjuk, 1451-ben készült Berlinben. A ma ismert fennmaradt kéziratok listájából csupán egyetlenegyre igaz ez: a München, Bayerische Staatsbibliothek, Clm 416 jelzetú kódexre. Ebben a kódexben sem jelenik meg a káplán neve, sem a mü incipitjében, sem explicitjében, azonban utóbbi a finitus in Berlin 1451-gyel zárul. E ponton fontos megjegyeznem, hogy a kéziratokkal foglalkozó szakirodalmak (Emil Trojel, Alfred Karnein) a szerző nevének azonosítására a mű címét, kezdő- vagy zárósorát vették alapul. Azonban Andreas káplán nevét elrejtette a szövegben, két helyen is olvashatjuk azt, először az első könyv hatodik fejezetében: Nam ea caecus continetur et amens, quos ab amoris curia penitus esse remotos amatoris Andreae aulae regiae capellani evidenter nobis doctrina demonstrat. ${ }^{9}$ Másodszor pedig a második könyv hatodik fejezetében fordul elö: Sed non gaudeat

\footnotetext{
${ }^{7}$ ARETIN (1803: 5).

8 ARETIN (1803: 5-6).

9 TROJEL (1892: 148). „Hiszen az még a vakot és az eszehagyottat is befogadja, holott azokat mindenképpen ki kell zárni Szerelem táborából, amint azt a szerelemben jártas Andreasnak, a királyi udvar káplánjának tanítása is világosan elénk tárja." RAJNAVÖLGYI (2012: 117).
} 
Andreas de eo quod magis cupit in orbe [...] ${ }^{10}$ Mindkét részt megtalálhatjuk a müncheni kéziratban, így véleményem szerint Von Aretin elsődleges forrása Hartlieb lehetett, nem pedig a latin kézirat, amely mellesleg Albertano nevét nem is tartalmazza.

A mü felkeltette François Just Marie Raynouard figyelmét is, aki 1817ben Choix de poésies originales des troubadours címü antológiájában bemutatta a párizsi ms. lat. 8758 jelzetü kódexben lévő XIV. századi De amorekéziratot. ${ }^{11}$ Raynouard kiemeli, hogy ez az értekezés az udvari szerelem egyik meghatározó müve.12 Őt követve hasonló megállapításra jut Arthur Dinaux is $1837-$ ben. ${ }^{13}$ Helytelen tehát, ha csupán Gaston Paris nevével azonosítjuk azt a kijelentést, hogy Andreas Capellanus De amore címü traktátusa az udvari szerelem kodifikációjának tekinthető, hiszen Paris előtt több mint nyolcvan évvel már Von Aretin, majd Raynouard is deklarálja ugyanezt. Paris mégis csupán Raynouard értekezését olvassa és hivatkozza, mindezt pedig kritikai szemmel teszi, és kijavítja utóbbinak szerinte helytelen átiratait. ${ }^{14} \mathrm{~A}$ De amore tehát már a XIX. század elején elfoglalja a szakirodalomban kiemelkedő helyét, ugyanakkor a mai napig Gaston Paris nevéhez kötik a tudományos diskurzusba való beemelését.

A második nyomtatott könyvet követően (1614) egészen 1803-ig senki nem foglalkozik a müvel, sem annak fennmaradt kézirataival, sem pedig recepciótörténetével. A XIX. századtól kezdve azonban napjainkig számos tanulmányt olvashatunk a XII. századi müről, annak müfajáról, az alkotó kilétéről, valamint a középkori szerelemfelfogásról. Egyedül Alfred Karnein érintette a De amore in volkssprachliccher Literatur ${ }^{15}$ címü

10 TROJEL (1892: 262). „Ám Andreas ne örvendjen sokáig annak, ami kívánatos számára ezen a világon [...]". RAJNAVÖLGYI (2012: 202).

${ }^{11}$ RAYNOUARD (1817: 80-83).

12 RAYNOUARD (1817: 83).

13 DiNAUX (1837: 49).

14 PARIS (1883: 459-534; 525-526). Ilyen átiratok közé tartozik Marie de Champagne levelének keltezése. Ez azért is érdekes, mert TROJEL a kritikai kiadásában jelzi, hogy ebben a kéziratban is az 1174-es dátumot olvashatjuk, miképp RAYNOUARD is, de Gaston PARIS félreolvasva, tanulmányában az 1176-os évet jelöli meg. Noha az egyik legolvashatóbb kéziratról van szó, nem mehetünk el amellett, hogy nem lehet teljesen pontosan meghatározni a keltezést: Ab anno M.C.LXXIIII R(?) Kal. Maii. indictione VII.

${ }^{15}$ KARNEIN (1985). 
monográfiájában a traktátus XV. századi recepcióját, amelyben kifejti, hogy a szerelmi traktátus alapját képezte a késő középkori latin nyelvü nevelődéstörténetnek. Megvizsgálva a mű keletkezését, hátterét és mondanivalóját, nyilvánvalóvá válik a népnyelvi irodalom genezisében betöltött jelentős szerepe. Mint azt Karnein megjegyzi, a káplán előtt senki nem írt korábban ilyen népnyelvi-poétikai amor-tanítást, amely így nagy befolyással bírt az ebben a témában később készült művekre. Megfigyelése szerint a recepció során mindig megújult a latin szöveg, újra és újra "felfedezték”, és az egyes újraírt változatok mind a recepció újabb fokozatait jelzik. Karnein monográfiája végén közli az általa ismert, és a XIII-XV. századi Európából fennmaradt 35 kéziratot, a további népnyelvű kiadásokat, említi az egyetlen fennmaradt inkunábulumot, valamint a két nyomtatott XVII. századi kiadást is $(1610,1614)$. Mindezek ellenére nem történt még meg a XIV-XV. századi kivonatolt, újrarendezett, parafrazeált kéziratos változatok alapos feltárása, sem pedig a mű korai, XVII. századi kiadásainak behatóbb vizsgálata.

Tanulmányomban Andreas Capellanus De amore címü értekezésének a német ajkú területeken megfigyelhető recepciótörténetét mutatom be az eddig általam feldolgozott kódexek alapján. A mintegy huszonöt kéziratból álló korpuszból csupán öt kéziratra szeretnék kitérni, amelyek a következőek:

1. Wolfenbüttel, Herzog-August-Bibliothek, Cod. 83.18 Auf. fol

2. Wolfenbüttel, Herzog-August-Bibliothek, Cod.71.20 Aug. fol

3. Kremsmünster, Stiftsbibliothek, Cod. 329

4. Kremsmünster, Stiftsbibliothek, Cod. 120

5. Bécs, Österreichische Nationalbibliothek, Cod. Vind. 5363

Problematikus kérdés a mü recepciójának vizsgálata, hiszen nagyban befolyásolja egy adott kézirat elemzését, hogy milyen szövegekkel másolták együtt, milyen célból és kik használták. Tartalmazza-e a kézirat mind a három könyvet, vagy csak egyet emel ki belőle, illusztrált-e vagy sem, töredékes vagy teljes? Más-más motívumot emelnek ki az egyes változatok, amelyek különböző értelmezési lehetőséget teremtenek. Éppen ezért a fentebb felsorolt öt kéziraton keresztül azt szeretném bemutatni, milyen módszer mentén igyekszem feldolgozni a mintegy huszonöt Közép-Kelet-Európában fellelhető De amore-kéziratot. A kódexek vizs- 
gálata során több szempontot is figyelembe vettem. Ezek közé tartozik Andreas nevének megjelenése a szövegben, Marie de Champagne levelének keltezése (1174. május 1.), valamint a traktátus címe és a szöveg felosztása. A területi csoportosításon kívül tehát érdemes tartalmuk alapján is osztályozni a kéziratokat. Nem mehetünk el amellett sem, hogy milyen szövegekkel másolták együtt a traktátust. Van, ahol több költőidrámai múvel együtt (Pamphilus de amore, Francesco Petrarca, Enea Silvio Piccolomini, valamint Ovidius írásai), máshol inkább filozófiai témájú szövegekkel együtt jelenik meg. A fennmaradt kéziratok között még egy csoportot elkülöníthetünk, amelyben a traktátust vallási és humanista szövegekkel együtt másolták. A Közép-Kelet-Európában fennmaradt 25 kézirat közül az általam is vizsgált krakkói kéziratban a nőgyülölet jegyében értelmezett harmadik könyv mellett találkozhatunk a pseudoovidiusi De Vetula címü XIII. századi, latin nyelven írott müvel is, sőt az ebből a korból fennmaradt kéziratok egy markáns csoportját alkotják azok a kódexek, amelyekben csupán a harmadik könyv szerepel.

\section{A kéziratok}

A kéziratok vizsgálata során egyértelmüen kimutatható, hogy a De amore sem a XIII., sem a XIV. században nem tünik fel német területeken, ám a XV. században teret hódít magának. Az elméleti értekezés jelenléte nemcsak nyomokban igazolható, épp ellenkezőleg, az évszázad elejétől a végéig jelen van. A században a következő szerzők műveiben érhetjük tetten a középkori szerelmi traktátust: 1404-ben Eberhard von Cersne saját költeményéhez a traktátus nagyobb részét felhasználja, majd 1440ben Johannes Hartlieb lefordítja népnyelvre az egész müvet. 1460-ban a Der Elende Knabe (Nyomorúságos fiú) című mü szerzője felhasználja a traktátusban szereplő szerelmi szabályokat. Ugyanebben az évtizedben Schoffthor a traktátusból a halottak seregéről szóló elbeszélést kiveszi és lovagi allegóriaként átkölti. A század végén pedig Hermann von Sachsenheim Neuen Liebe Buch címü munkájában áthallani Capellanus müvét. ${ }^{16} \mathrm{~A}$ XIV. és a XV. századból ezenkívül nagyjából tíz latin nyelvü, német ajkú területen található kódex maradt fenn.

16 KARNEIN (1985: 245). 
A bécsi nemzeti könyvtárban őrzött Cod. Vindobonensis 5363-as jelzetü kódex a szakirodalom jelen állása szerint a XIV. századra datálható. Ugyanakkor a papír megvizsgálása során talált vízjelek arra engednek következtetni, hogy jóval később, a XV. században keletkezett. A 115 fólióból álló gyüjteményes kézirat a káplán traktátusán kívül (1r-60v) Johannes de Mandevilla Iter Hierosolymitanum címü múvét is tartalmazza (61r-115v). Noha címében nem jelenik meg a káplán neve: Incipit liber amoris et cortesie, a traktátusban két helyen is olvashatjuk a szövegben elrejtett szerzői nevet ( $25 \mathrm{v}$ és $44 \mathrm{v})$. A grófnő levelét a másoló helyesen az 1174-es évre datálja, ugyanakkor az értekezés hármas felosztását nem követi, az első két könyvet egynek veszi és további egynek a harmadikat.

Hasonló felosztást alkalmaz a XV. századi wolfenbütteli 83.18-as jelzetü kézirat másolója is, csak ő már címet is ad a második könyvnek, amely voltaképpen a harmadik: Liber de reprobatione amoris. A káplán neve egyáltalán nem jelenik meg sem a mü címében (De reprobatione et eius remedio. De arte amandi) ${ }_{1}^{17}$ sem pedig abban a két fejezetben, ahol a káplán elrejtette nevét. A Champagne grófnője által írt levél keltezése sem pontos: az 1174. május 1 . helyett 1210 szeptemberét olvashatjuk. A historiografikus-irodalmi szövegekkel együtt másolt kézirat ${ }^{18} 149$ versóján pedig a másolás időpontját olvashatjuk: Et sic finitur tractatus de reprobatione amoris et de eius remedio 1442. 5. Julii. Deo gratias.

Ezzel szemben a szintén Wolfenbüttelben található 71.20-as jelzetü kódex már nem tartalmazza a levél dátumát. A traktátust három részre osztja, de a felosztása más rendszert követ: a második rész a klerikusok szerelmével kezdődik, noha az még az első könyvhöz tartozna. A harmadik könyv az Incipit liber de reprobatione amoris címet viseli. Érdekes ugyanakkor, hogy Andreas neve sem a mü címében, sem abban a két fejezetben nem szerepel. Előbbi a Pogius de amore et arte amandi et de remediis Amoris, utóbbi pedig Ovidius nevével fémjelzi az értekezést. Pogius nevét egy másik kéz írta, ahogyan a 303 verso alján is ezt olvashatjuk: Pogius de arte amandi et ipsius artis reprobatione. A kódexben ezen-

\footnotetext{
17 A mü címe utólagosan került feljegyzésre, más tintával, más-más kéztől.

18 1r-92v: Guido de Columna vel de Messana Historia Trojana, utána egy másik kézzel írva: Dulcis amor semper tristis amaror erit. 93r-149v: Liber vel Tractatus de reprobatione amoris et de eius remedio, auctore Andrea capellano regio Francorum.
} 
kívül még Petrarcától olvashatunk (1r-230v: Francisci Petrarchae liber de remediis utriusque fortunae), de a 240r-304v: Pogius de amore et arte amandi et de remediis Amoris, azonos nevü és címü, de tartalmában más szöveget találunk. A kézirat végén egy, a káplán szerelmi traktátusából készült florilegiumot találunk (304r-304v: Florilegium).

Az 1480-ban készült Codex Cremifanensis 329-es jelzetü kódex nem osztja könyvekre az értekezés szövegét. ${ }^{19}$ A cím nélküli szövegben a megadott két helyen olvashatjuk Andreas nevét, így kapcsolódik a bécsi kézirat hagyományához. A grófnő levelének keltezése itt sem az eredeti dátumot tartalmazza: itt 1184. májust olvashatunk.

A kremsmünsteri Stiftsbibliothekban őrzött 120-as jelzetü kódex a XV. századból való. ${ }^{20}$ A $114 \mathrm{v}-n$ egy bejegyzést olvasunk 1770 . szeptem-

${ }^{19}$ A kéziratban található többi szöveg: 2r-74v: Fasciculus temporum omnes antiquorum cronicas complectens, 75r-80v: Sixti IV. papae constitutiones, 81r-126r: Liber de remedio Amoris/Ars amandi, 126v-131v-ig üres, a 130-131 között ki lett tépve egy lap, de a számozást ez nem befolyásolta. 132r-164v: Incipit Cronica summorum pontificum Imperatorumque ac de septem etatibus mundi ex s. Ieronomi, Eusebio aliisque eruditis excerpta, Et primo de septem etatibus mundi. 165rv üres, 166r-179v (első kolumnájáig): Augustini Dati aliqua documenta diligentissime composita ad Anthonium amicum suum carissimum, 179v (második kolumnájától)-204v: P. Ovidii Nasonis epistolae (Heroides XX et epistola Sapphus ad Phaonem), 205r-209r: Ladislai Vetesij Pannonij Cubicularij apostolici oracio ad summum sanctissimumque pontificem Sixtum quartum pro prestanda obediencia nomine Invictissimi principis divi Mathie serenissimi Hungarorum et Bohemorum Regis Quarto Nonas Februarii 11oCCCCoLXXVo, 209v-211v: Epistola Enee silvij poete laureati sive pij pape secundi de amoris remedio incipit!, 211v-224v (elsö kolumnájáig): Ladislai Vetesij ad Ubertinum Carrariensiem de ingenuis moribus opus, $224 \mathrm{v}$ (második kolumnájától)-230r (első kolumnájáig): De magno Basilio Leonardi Aretini Traduccio ad Colucium, 230r (második kolumnájától)-236v: De Xenophonte Leonardi Aretini Traduccis de Tyrannide, 237r-253r: Incipit tractatulus de duobus se invicem diligentibus compositus per dominum Eneam Silvium poetam Imperialemque secretarium qui tandem ad summum apostolatus apicem assumptus Pius papa Secundus vocatus est, 253v-256v: Sixti IV. papae de Urbe cum Indulgentiorum aliarumque gratiarum elargitione renovatio confraternitas priorum virorum in Archihospitale (?) S. Spiritus in Saxia, 256v-259r: Credencia ad sanctissimum patrem nostrum summum pontificem per Anthonium de Morthone, 259v-264v (első kolumnájáig): Acta spectantia ad pacem Olomuci factam 1479 inter Mathiam regem Hungarie et Vladislaum regem Bohemie, 264r (második kolumnájától)-265v (első kolumnájáig): Sixti IV Papae Bulla contra abusus advocatorum circa beneficia vacantia in diocesi Passau, 265v (második kolumnájától)-266r: Copia Bulle Indulgenciarum super psalteris gloriose virginis Marie, 266v-269v: üres.

${ }^{20}$ A kódexben szereplő szövegek a következőek: 1r-110v: Augustinus: In libros XXI de Civitate dei (notae), 115r-132v: Incipit Aurea Bulla, Caroli IV., 133r-141v: Tractatus anepig- 
ber 26-i dátummal: „A kódex eddigi szövegét javította és kiegészítette: Johann Paulus Wartha." Wartha a kremsmünsteri apátság keleti, 1755től héber és 1756-tól görög nyelvtanára volt. A traktátus cím nélkül kezdődik, nincs felosztva három könyvre, a bennük lévő fejezetek nem különülnek el egymástól. Andreas neve - az Ms. 329-hez képest - csak egyszer jelenik meg a szövegben, sőt a mű explicitjében Enea Silvio Piccolomini nevét olvashatjuk - mint aki lediktálta ezt a történetet a scriptornak.

\section{A szöveg átalakulása}

A kéziratok vizsgálata során kiindulópontként Emil Trojel latin nyelvü kritikai kiadását vettem alapul. ${ }^{21}$ Az előszóban 12 kódexet nevez meg, majd mutatja be részletesen azokban a De amore szövegét. Igyekszik megadni ezek provenienciáját, és leíró katalógust készít róluk. ${ }^{22}$

A Trojel által vizsgált kéziratok közül négy az én korpuszomnak is részét képezi, ezért fontos támpontja a kutatásomnak. A De amore jelenleg ismert kéziratai közül a legelső a XIII. század utolsó harmadából ismert, ma a Vatikáni Könyvtár őrzi. ${ }^{23}$ A legutolsó ismert kézirat 1503-ból

raphicus: an iure aliquo ipsum excelsum dominium subsit imperatori maiestati, 142r-179v: Excerpta ex libello Restitucionum fratris Francisci de platea bononiensis ordinis minorum, 182r-246v: Tractatulus de amoris arte et eius remedio, editus est opus Andreae Capellani, cui titulus: Ars amandi, 251r-270v: Enea Silvii Historia de duobus amantibus.

21 TROJEL (1892: 1-56).

${ }^{22}$ Az általa vizsgált kéziratok a következőek: Milánó, Biblioteca Ambrosiana, Cod. A 136 sup, XV. század; Wolfenbüttel, Herzog-August-Bibliothek, Cod. 83.18 Aug. fol, 1442; Róma, Biblioteca Vaticana, Cod. Ottob. lat. 1463A, XIII. század; Párizs, Bibliothèque Nationale, ms. lat. 3758, XIV. század; Montpellier, Bibliothèque de l'Ecole de Médicine, Cod. 217, XIV. század; Firenze, Biblioteca Medicea Laurenziana, Cod. Gadd. 178, XV. század; Wolfenbüttel, Herzog-August-Bibliothek, Cod. 71.20 Aug. fol, XV. század; München, Bayerische Staatsbibliothek, Clm 416, 1451; Párizs, Bibliothèque Nationale, ms. lat. 10363, XV. század; Lipcse, Universitätsbibliothek, Cod. 1593, XV. század; Brugge, Bibliothèque Publique, Cod. 479, XV. század; Bécs, Österreichische Nationalbibliothek, Cod. Vind. 5363, XV. század.

${ }^{23}$ Róma, Biblioteca Vaticana, Cod. Ottob. lat. 1463A, A De amore mellett a következő szövegeket olvashatjuk benne: 1r-30v: De rebus Alexandri magni, 79v-80v: Officium in missa pro concordia Exaudi domine vocem meam qua clamavi (Ps 26.7), 81r-105v: De Gestis Frederici Imperatoris. A 31r-n a következőt olvashatjuk: Incipit liber amoris et curtesie ab andrea capelano regis francie compositus. Fejezetcímeket nem jelöl, sőt az első könyv végét 
való, német nyelvü és jelenleg magántulajdonban van. Utóbbit Wolfgang Beeh mutatta be, és a következő megállapításokat tette: a kézirat egy frankfurti patrícius családból származó férfi és egy alacsonyabb rangú nő házassága alkalmából készült, Heilmann Stralenberg és Elisabeth Kuhle számára. ${ }^{24}$ A kézirat igen gazdagon illusztrált, 19 miniatúrát tartalmaz. ${ }^{25}$ A megkötött frigy kellemetlenül érintette a Stralenberg családot, ez gyermekeikre is kihatott - nem vették fel őket az AltenLimpurg házba. ${ }^{26} \mathrm{Ha}$ rangon aluli házasság köttetik, akkor általában szerelmi házasságnak szokták tartani. Éppen ezért jól látszik, hogy a XVI. század elejére egyrészt a laikusok számára készült a traktátus másolása, másrészt olyan frigyek ajándékául szolgált, amelyek valódi szerelmen alapultak.

A recepciótörténet hipotéziseinek felállítása során ez a két dokumentum kulcsfontosságú. Míg a XIII. században még morálteológiai szövegekkel együtt másolják a De amore szövegét, és a klerikusok kezei között forog, addig a XIV-XV. századra egy paradigmaváltást figyelhetünk meg: először egyházi szövegek mellett találjuk, majd később humanista múvekkel együtt kezdik másolni, és egyre inkább a laikusok körében terjed, míg a XV. század végére csupán a szerelem mintakönyve lesz. Véleményem szerint ennek a paradigmaváltásnak az eredménye, hogy a De amore igenis hatással lehetett nemcsak a népnyelvi lovagi-didaktikus irodalomra, hanem a költészetre egyaránt - bár ezt Karnein elveti arra hivatkozva, hogy éppen a népnyelvü fordítások miatt nem lehetett forrása a költőknek. ${ }^{27}$

Andreas Capellanus müvét elsőként Albertano da Bresciánál olvashatjuk. Albertano kitünő ügyvéd és politikus volt. 1238-ban összekülönbözött II. Frigyes német-római császárral, és ennek következményeként a cremonai börtönbe került. Itt volt rá ideje, hogy megírja első (?) könyvét (De Amore dei et proximi et aliarum rerum), amelyben többször is idézi

és a második könyv elejét a következőképpen olvashatjuk: Explic(it) lib(er) I. incip(it) II. Majd egyéb megjegyzés nélkül a 72v-n kezdődik a harmadik könyv.

${ }^{24}$ BEEH (1966: 53-82).

${ }^{25}$ Fontos megjegyezni, hogy ez az egyedüli illusztrált De amore-kézirat.

${ }^{26}$ LERNER (1952), KÖRNER (1971).

27 KARNEIN (1985: 120-240). 
a káplán müvét. Szabadulását követően 1245-ben születik a következő müve: De arte loquendi et tacendi, amelynek szintén egyik forrása volt Andreas müve, majd egy évvel később a Liber consolationis is napvilágot látott. Ezekben az években számos prédikációt is ír, ebből mindössze öt maradt fenn..$^{28}$

Alfred Karnein behatóan elemzi Brescia idézeteit, amelyekből kiderül, hogy elsődlegesen az amor-tanítás meghatározásához használta fel a traktátus szövegét. Különbséget tesz az amor mint caritas, és az amor mint cupiditas között. ${ }^{29}$ Ezután Albertano a következő alfejezetekben idéz Andreas káplán 31 szerelmi szabályából 16-ot, de nem ugyanabban a sorrendben, mint az eredetiben szerepel, hanem témák szerint csoportosítva. A De arte loquendi et tacendi című munkájában javarészt megint csak a szerelmi szabályokból idéz, és saját véleményét ezek alátámasztásával fejti ki. Például amikor a gúnyos megjegyzésekről beszél, a 19. szerelmi szabályt hozza fel, amely így hangzik: XIX. Nam dicit regula amoris: Si amor minuatur cito deficit et raro convalescit. ${ }^{30}$ - Albertano a következőképpen építi be saját szövegébe: Irrisio facit, ut amor inter eos minuatur, et secundum regulam amoris: si amor minuatur, cito deficit et raro convalescit. ${ }^{31}$

A további vizsgálatok azonban arra engednek következtetni, hogy a Gualteriusnak ajánlott mü és a benne lévő szerelem szabályai két, egymástól különálló müként aposztrofálódtak Albertano számára, mivel Karnein filológiai vizsgálatokkal bizonyította, hogy más a forrása a szerelem szabályainak és más a traktátus kezdősorának, az amor est passiónak ebben a században. Utóbbit de quo Galterus tractavitként értelmezi, mivel a traktátus kézirata, amit Albertano használt, a liber Galteri de amore címet viselte. Pio Rajna és Robert Bossuat munkájukban rámutatnak arra, hogy a XIV. és a XV. században a szerelem szabályai önálló müként jelentek meg, sőt Észak-Itáliában a regole d'amore néven váltak ismertté a népnyelvű kéziratokban. ${ }^{32}$ A szerelmi szabályok önálló pálya-

\footnotetext{
28 Életéről bővebben ld. SUNDBY (1873).

${ }^{29}$ KARNEIN (1985: 110-114).

30 „Ugyanis a szerelemnek szabálya kimondja: Ha a szerelem lanyhul, hamarosan meg is szünik, és csak ritkán éled újra." RAJNAVÖLGYI (2012: 236).

31 SunDBY (1873: 163). „Csúfolódj, úgy, ahogy a szerelem lanyhul közöttük, a szerelem szabálya szerint: ha a szerelem lanyhul, hamarosan meg is szünik, és csak ritkán éled újra." 32 KARNEIN (1985: 112), RAJNA (1891: 193-272), BOSSUAT (1926).
} 
futását mutatja az is, hogy a késő XIII. századból származó vatikáni kézirat Cod. Reg. lat. 358-as kódexe megőrizte azt a florilegiumot, amely Geremia da Montagnone Compendium moralium notabilium című müvében olvasható. A tematikusan összeállított idézetgyüjteményt Montagnone 1295 körül írta meg Padovában, ahol 1280 és 1321 között bíróként dolgozott. ${ }^{33}$ Míg Albertano a bujaságot és a hamis szerelmet mutatja be, addig Geremia épp a testi szerelem elítélésére hoz példákat, többségében a traktátus harmadik könyvéből. Ugyanakkor megidézi a szerelmi értekezés eredeti szerzőjét, amit a 71r-n olvashatunk: Excerpta de libro de amore andree capellani ad galtherus (sic!). ${ }^{34}$ Úgy tünik, a XIII. század végére a káplán művéből inkább a traktátus harmadik könyvét idézték és használták fel. Ezt mi sem bizonyítja jobban, mint hogy a mú egyik kiemelkedő sorát - amor est passio - negatív konnotációval illették. A XIV. század közepén Konrad von Halberstadt, ${ }^{35}$ valamint rotterdami Arnold Gheylhoven florilegiuma ${ }^{36}$ is Montagnone Compendium címü művén alapul. Ez utóbbi florilegiuma a Tripartium moralium című művének első részében olvasható, és teljes egészében Montagnone idézeteit használta fel alfabetikus sorrendben. ${ }^{37} \mathrm{Az}$ általam vizsgált krakkói kézirat tartalmazza mind a káplán, mind Konrad szövegét. Az 1447-re datált Incipit Gwalterus doctor amoris kezdetü De amore-szöveg is valószínúsíthetően a XV. században készült, és Itáliából került a lengyel városba.

Az idézetgyüjtemények önálló művé értek a XV. században, a törzsszöveg nélkül kerültek egyes kéziratokba: Róma, Biblioteca Vaticana, Cod. Ross. 1097, valamint az általam behatóan vizsgált wolfenbütteli kézirat (Cod. 71.20) - ahogyan fentebb említettem - is tartalmaz florilegiumot. A két kézirat azért is érdekes, mivel mind a kettő tartalmazza a teljes De amore szövegét is a florilegium mellett, sőt egy teljesen más szerzőt neveznek meg a szerelmi értekezés auktorának: míg a korábbi

\footnotetext{
33 WEISS (1949: 15-20).

34 Róma, Biblioteca Vaticana, Cod. Reg. Lat. 358, 71r-72r.

35 MUNK (1995: 145-273).

${ }^{36}$ KAEPPELI (1970: 278).

37 Tripartitus moralium: Abiicere temporalia. Hermes Trismegistus in libro de deo deorum ad Asclepium [...]. Krakkó, Biblioteka Jagiellonska, Cod. 5230.
} 
Alanus $^{38}$ nevét tartalmazza, addig az utóbbiban Pogiust ${ }^{39}$ olvashatunk. A Rómában található kézirat $1446-{ }^{-10}{ }^{40}$ a wolfenbütteli szintén a XV. századra datálható. A könyvtár dolgozói ez utóbbi kéziratnak előkészítése során megjegyezték, hogy nem tartalmaz vízjelet, sőt a szakirodalom is így vélekedik, azonban nekem mégiscsak sikerült találnom kettőt is: a papír, amelyen Capellanus szövege található, az 1420-as évekre datálható, míg az, amelyiken a florilegium olvasható, 1431-re. ${ }^{41}$

A florilegiumok vizsgálata azért is fontos, mert Nicolaus Sculteri által láthatjuk, hogy Itáliából hogyan került német területre a traktátus szövege. Sculteri Frankfurtból származott, 1423-ban Padovában jogot tanult, és a kánonjogi feljegyzései közé írta florilegiumát, amely a $D e$ amore szövegét tartalmazta. ${ }^{42}$ A berlini, Staatsbibliothek, Preuß. Kulturbesitz, ms. 840 jelzetü, az 1424. évre datálható kézirat 220v lapján a következőt olvashatjuk: Auctoritates Andree ad Gualterium de arte amandi. Sculteri a tanulmányai befejeztével rögtön visszatért hazájába, ugyanis 1424-től már a lipcsei egyetem rektori posztját töltötte be. A kézirat másik tulajdonosáról is vannak ismereteink: egy bizonyos Matheus Prenne volt, aki 1448-ban Stendhalban rector altaris s. Pauli, majd 1474-ben Lebusban canonicus ecclesie volt. Ez a gyüjtemény negyven idézetet tartalmaz, és feltárja a férfi és nő között lévő szerelem mibenlétét. Ebben a De amore szövegének újabb értelmezését láthatjuk: a XIII. században Geramiánál még az egyházi tanítás uralkodik, és a szerelmi értekezés harmadik könyvéből származnak az idézetek. Ezzel szemben a XV. szá-

\footnotetext{
38 Alanus de Arte amandi Et remedio Amoris - Róma, Biblioteca Vaticana, Cod. Ross. 1097, 1r, a florilegium 123 idézetet tartalmaz a De amore harmadik könyvéből, 122r-124r: Erit fletus et stridor dencium-tól Solomonis demonstrat exemplum-ig.

39 Pogius de amore et arte amandi et de remediis amoris - Wolfenbüttel, Herzog-AugustBibliothek, Cod. 71.20 Aug. fol. 240r, de nem ugyanaz a kéz írta, mint aki a szöveget jegyezte le. 303v: Pogius de arte amandi et ipsius artis reprobatione. Florilegium: $304 \mathrm{r}-304 \mathrm{v}$, az egész traktátusból.

40 Finitus Rome Anno domini 1446 sancté die nativitatis iohannis Baptiste - Róma, Biblioteca Vaticana, Cod. Ross. 1097, 122r.

${ }^{41}$ A kódex így mindenféleképpen a XV. század első felére datálható.

42 VALENTIN (1901: 943-946).
} 
zadban már az itáliai és így a német területeken már egy újfajta szerelemfelfogás bontakozik ki: a bünöktől mentes világi szerelmi kapcsolat. ${ }^{43}$

\section{Recepció}

Az általam vizsgált több mint húsz kelet-közép-európai latin nyelvű $D e$ amore-kézirat eddig feldolgozott anyagairól elmondhatom, hogy a traktátus német recepciója észak-itáliai közvetítéssel történt. Az Itáliában tanuló német humanisták megismerkedhettek az elméleti értekezéssel, hiszen feljegyzések támasztják alá, hogy az az értelmiség oktatásának részét képezte Észak-Itáliában. ${ }^{44}$ Ott már a XIV. században jól ismert, sokat idézett és fordított müként tartották számon. Ezt az is jól bizonyítja, hogy a két legkorábbi fennmaradt kézirat a XIII. századi Itáliában készült, jelenleg a Vatikáni Könyvtár őrzi őket. Az is biztos, hogy Padovában az egyetemen ismert volt a traktátus szövege, ahogyan ezt Nikolaus Sculterinél és Schedelnél is láthattuk. Az is világossá válik, hogy a XIII. század erkölcsi rendszerében a férfi és nő közötti erotikus kapcsolat pozitív értékelése nem volt lehetséges, csupán speciális formákban: versekben, regényekben jelent meg. ${ }^{45} \mathrm{~A}$ De amoréban lévő amor egyik

${ }^{43}$ Ezt reprezentálja, hogy az ebből az időszakból származó florilegiumokban lévő idézetek az első könyvből (Liber primus) származnak.

${ }^{44}$ Nicolaus Sculterin kívül Hartmann Schedelről tudunk, aki a szerelmi szabályokat itáliai útja során ismerte meg, és Ovidius Ars amatoria című művével hozta kapcsolatba. Ő szintén Padovában találkozott a traktátussal, hiszen ott folytatta tanulmányait 1463-tól 1466-ig. Schedel életéről ld. POSSELT (2016: 87-124), SCHNELL (2016: 75-86), WIENER (2016: 125-144).

${ }^{45}$ Itt elsősorban a népnyelvű fordításokra, valamint a traktátus felhasználásával készült, szintén népnyelvü müvekre gondolok: a XIII. században két francia nyelvü fordítás született, az első egy prózai változat, amelyből csak néhány részlet maradt fenn a Doctrinae d'Enanchetbe illesztve. Itt a Szűz Mária iránti szerelem bemutatása jelenik meg. A másik Drouart la Vache Les livres d'Amours címü múve 1290-ből. A XIV. században itáliai területeken: Albertano da Brescia múve, a De dilectione Dei et proximi aliarum rerum et de forma honestae vitae. Jean de Meun és Guillaume de Lorris: Roman de la Rose (felhasználja a szerelem definícióját), Jeremias de Montagnone: Compendium moralium notabilium. Jakes d'Amiens szintén felhasználja a L'art d'amors címü müvében (különböző társadalmi helyzetű nők és férfiak beszélgetnek dialógusformában - ahogyan a káplán múvében is). Richard de Fournival Amitiés de vraie amour címü múvében átveszi a szerelmi szabályokat, valamint kiemeli, hogy a szerelem ex visione történik akárcsak a traktátusban. Egy másik müvében, a Conseil d'Amour-ban bemutatja azon 
lehetséges megnyilvánulása a cupiditas, és nem a caritas, ami a szerelem legalacsonyabb formáját jelentette. Ezért nem meglepő, hogy Geremia Compendium moralium címü müvének amor-tanításában az utóbbi kerül előtérbe. Albertano ezzel szemben a traktátus egy másik értelmezési lehetőségét ragadta meg: a nők iránti vágy megjelenését. Az ő esetében jól látszik, hogy a traktátus eredetileg is az udvar számára készült, itt is ez a célközönség jelenik meg.

Az elméleti értekezés népszerüsítésének fontos állomása, amikor Johannes Hartlieb 1440-ben lefordítja népnyelvre a De amorét Bécsben. ${ }^{46}$ Ajánlásában világossá válik a megrendelő személye is: VI. Albert. Már az ajánlásból is következtethetünk arra, hogy ekkortájt a német területeken a nemesség olvasta az elméleti értekezést, sőt VI. Albert az ajánlás idején 22 éves, vagyis éppen abban a korban van, amit Andreas a célközönségét illetően meghatároz. Hartlieb ugyanakkor nem ismeri a traktátus eredeti szerzőjének a nevét, így tévesen egy Albertanus nevü mestert nevez meg helyette. Ez a név feltételezhetően Albertano da Brescia nevét rejti, ami egy újabb bizonyíték arra, hogy a traktátus Itáliából érkezett a német területekre. Tudomásunk van egy kéziratról a XIV. századból, amelynek tulajdonosa Oliviero Forzetta itáliai polgár, kereskedő volt, aki végrendeletében könyveinek egy részét a trevisói Szent Margit konventnek adományozta. Az 1374. november 29-re keltezett, az átadást bizonyító okirat a kéziratot liber amoris et cortesie címen jelöli, szerző nélkül. 1378-ban a konvent könyvtárának jegyzékében a következőt olvashatjuk: Item libellus qui dicitur amoris et cortesi Aglbertani. Principium: 'Cogit me'. Finis: 'ediderem'. Item in eodem. De Reprobatione amoris Principium: 'Si hec'. Finis: 'neque horam; cum tabulis et modico corio rubeo lacerato. ${ }^{47}$ - Ez a katalógusbejegyzés árulja el számunkra, hogy valószínüleg ez volt Hartlieb mintája a fordítás során. Ugyanakkor fontos megemlíteni,

nők büntetését, akik a szerelmet elutasítják. Antonio Pucci a Libro di varia storiában és a Brutto di Bretagnában felhasználja a breton lovag történetét. Alain Chartier La belle dame sans merci y Complainte d'Amours avec sa reponse címü művében az első könyv szerelmi dialógusait követi. Martialis d'Auvergne az Arrets d'Amours-ban a szerelmi ítéleteket felhasználva megalkotja a saját szabályait. Ezeken kívül még katalán és spanyol versekben is olvashatjuk.

46 GROßMANN (1929: 150-325; 199).

${ }^{47}$ GARGAN (1978: 130). 
hogy a capellanusi kézirat-hagyományban három kézirat is viseli a liber amoris et cortesie címet - ezek közül az egyik a XIII. századi, Vatikáni Könyvtárban őrzött kézirat, a második a Karnein által tévesen XIV. századra datált, de vizsgálódásom szerint későbbi, XV. századi bécsi kézirat, végül pedig a XV. századi uppsalai kézirat. Ezek közül csupán a bécsi kézirat nem tartalmazza incipitjében az Andreas nevet. Kézenfekvő lenne azt állítani, hogy ez lehetett Hartlieb forrása, de a szöveg a későbbiekben (első és második könyvben) megnevezi valódi szerzőjét: Andreas Capellanust. Az általam tanulmányozott wolfenbütteli 71.20-as jelzetü kódex vizsgálata során felmerült a kérdés, hogy talán az volt Hartlieb egyik forrása, hiszen az Andreas nevének helyén lévő Ovidius névvel itt találkozunk - ahogyan azt Hartlieb is közli fordításában. Azonban az összevetés során hiba lenne azt állítani, hogy ténylegesen ez lehetett a fordítandó szöveg: például a XIV. szerelmi szabály hiányzik a kéziratból, de Hartlieb fordításában megtaláljuk, s a szabályok sorrendje sem azonos a két szövegben, előbbiben: I, II, V, VI, III, IV, VII, ezzel szemben a német nyelvű szövegben az elejétől végéig helytálló a felsorolás számozása. Ezt a feltételezést igyekszik alátámasztani az is, hogy Hartlieb szöveghüen fordított, a könyvet bevezető és befejező megjegyzésekkel látta el, amelyek leginkább a traktátus nőellenes megnyilvánulásaiért tett bocsánatkéréseket tartalmazzák. Mivel Wolfram Schmitt tanulmányából tudjuk, hogy Hartlieb 1439-ben Padovában doktorált, majd innen ment Bécsbe ${ }^{48}$ nyilvánvalóvá válik, hogy ott ismerkedett meg a traktátussal, és forrása a mára elveszett trevisói kézirat volt.

A szerző nevének tévesztése egyértelműen a mintaként szolgált latin kéziratból adódik.

A capellanusi kézirat-hagyományban előfordul, hogy a szerző neve vagy egyáltalán nem jelenik meg, vagy tévesen. Ahogyan fentebb is említettem, Albertano da Brescia nevével csupán egyetlen kéziratban találkozunk, így feltehetően ez volt Hartlieb forrása is. Egy másik esetben Alanus neve jelenik meg a mü címében: Alanus de Arte amandi Et remedio Amoris, aki valószínúleg a skolasztikus filozófus, Alanus de Lille lehetett (Róma, Biblioteca Vaticana, Cod. Ross. 1097). Szintén egyetlen kézirat címében olvasható Pogius, észak-itáliai humanista neve: Pogius de amore

48 SCHNELL (2007: 444-448; 447). 
et arte amandi et de remediis amoris. (Wolfenbüttel, Herzog-AugustBibliothek, Cod. 71.20 Aug. fol.). Az Enea Silvio Piccolominitől eredeztetett szöveg a kremsmünsteri kódex explicitjében található: Explicit tractatulus de amoris arte et eius remedio editus ut fertur ab Enea Silvio poeta Laureato (Kremsmünster, Stiftsbibliothek, Cod. 120.). ${ }^{49}$ A harmadik könyvből csupán részleteket tartalmazó brüsszeli kézirat scriptora azonosítja Boncompagnóval a traktátus szerzőjét: Liber qui dicitur amicitia magistri Boncompagni (Brüsszel, Bibliothèque Royale Albert Ier, Cod. 1890-1892). Hat esetben pedig Gualterius neve jelenik meg, akinek a káplán ajánlotta a szerelmi értekezést (Montpellier, Bibliothèque de l'Ecole de Médicine, Cod. 217; Berlin, Staatsbibliothek, Preuß. Kulturbesitz, ms. lat. $4^{\circ} 239$; Krakkó, Biblioteka Jagiellonska, Cod. 5230; Prága, Universitätsbibliothek, Cod. XIV, E29; Brugge, Bibliothèque Publique, Cod. 479; Lüneburg, Ratsbücherei, Cod. Theol, folio ${ }^{\circ} 49$ ).

A szerelmi értekezés recepciótörténetének paradigmaváltását figyelembe véve joggal tehetjük fel a kérdést, hogy Hartlieb fordítása melyik kategóriába esik. Sajnos ezt nehéz megítélni, mivel pontos fordítását adja meg a latin nyelvü traktátusnak, viszont egy érdekes életrajzi adat némi segítséget nyújt ennek feltérképezésében. Hartlieb kiemelt figyelmet szentelt a pszeudo-természettudományi, pontosabban az okkultista müveknek, az ebbe a témába tartozó, holdjóslásról, névjóslásról, tenyérjóslásról szóló műveket előszeretettel fordította népnyelvre. ${ }^{50} \mathrm{~A}$ De amore fordítása ebből az aspektusból nem tünik meglepőnek, hiszen 1277-ben Tempier püspök dekrétumában elítéli és betiltja a traktátus másolását, olvasását. Hartlieb fordításának egyébként nagy sikere van, hiszen a XV. században 11 kézirat őrzi munkáját, és 1482-1484 között három nyomtatott kiadás is született. Karnein közelebbről is megvizsgálta Hartlieb munkáját és a fennmaradt kéziratokat. Arra a következtetésre jutott, hogy ezek gondosan tagolt, rendezett példányok, amelyek bizonyára nemesi családok számára készültek.51

\footnotetext{
${ }^{49}$ Ennek oka egyrészt magyarázható előbbinek a De remedio amoris című munkájával is, másfelől viszont okot ad annak feltételezésére, hogy Piccolomini behatóan ismerte a múvet, utalt rá, amely a scriptor másolása következtében megemlítésre került.

50 SCHMITT (1982: 255-271; 584; 244-271).

${ }^{51}$ KARNEIN (1970).
} 
Összességében tehát elmondhatjuk, hogy Andreas Capellanus De amore című szerelmi traktátusának recepciótörténete a német ajkú területeken egy összetett folyamat eredményeképpen írható le. Ahogyan fentebb is láthattuk, ezekre a területekre itáliai közvetítéssel került a szöveg, ami az Itáliában tanuló német humanistákhoz köthető. Az egyházi szövegekkel együtt másolt szerelmi értekezés a XV. század végére a szerelem mintakönyve lett, vagyis ismét azt a funkcióját töltötte be, amit a káplán a XII. században feltehetőleg meghatározott: erkölcsi tanítás helyett a szórakoztatás került előtérbe. Hartlieb népnyelvi fordítása a traktátus szélesebb körben történő elterjedését tette lehetővé, amely így számos népnyelvü mü alapját képezte.

\section{Források}

RAjNAVÖlgyi 2012 RajNAVÖLgYI G. (ford.), Andreas Capellanus: A szerelemről, Budapest, 2012.

Trojel 1892 E. Trojel (ed.), Andreae Capellani Regii Francorum De amore libri tres, Havniae, 1892.

\section{Felhasznált irodalom}

ARETIN 1803

BEEH 1966

BOSSUAT 1926

DINAUX 1837

GARGAN 1978

GROßMANN 1929

KAEPPELI 1970

KARNEIN 1970
J. Ch. F. von ARETIN, Aussprüche der Minnegerichte: Aus alten Handschriften herausgegeben und mit einer historischen Abhandlung über die Minnegerichte des Mittelalters begleitet, München, 1803.

W. BEEH, Eine spätgotische mittelrheinische Handschrift "Über die Liebe zu erwerben und die Liebe zu verschmähen", Kunst in Hessen und am Mittelrhein 6 (1966), 53-82.

R. BossuAT, Drouart la Vache, Traducteur d'Andre le Chapelain (1290), Párizs, 1926.

A. DINAUX, Trouvères, jongleurs et ménestrels du nord de la France et du midi de la Belgique, vol. 3, Téchener, 1837.

L. GARGAN, Cultura e arte nel Veneto al tempo del Petrarca, Studi sul Petrarca 5 (1978), 16-354.

K. GrobmanN, Die Frühzeit des Humanismus in Wien bis zu Celtis Berufung 1497, Jahrbuch für Landeskunde von Niederösterreich 22 (1929), 150-325.

T. KAEPPELI, Scriptores Ordinis praedicatorum Medii Aevi, vol. 5, Róma, 1970.

A. KARNEIN, De amore deutsch: der Tractatus des Andreas Capellanus in der Übersetzung Johann Hartliebs, vol. 28, in: Münchener Texte und Untersuchungen zur deutschen Literatur des Mittelalters, München, 1970. 
KARNEIN 1985

KIM 2010

KÖSZEGHY 2012

MunK OLSEN 1995

PARIS 1872

PARIS 1883

PARIS 1884

PARIS 1888

POSSELT 2016

RAJNA 1891

RAYNOUARD 1817

SCHMITT 1982

SCHNELL 2007

SCHNELL 2016

SUNDBY 1873

VALENTIN 1901

WEISS 1949

WIENER 2016
A. KARNEIN, De Amore in volkssprachlicher Literatur, Heidelberg, 1985.

J.-H. Ph. KIM, L'Amour courtois« de Gaston Paris: une lecture décadente du Chevalier de la Charrette?, The French Review 83/3 (2010), 589-606.

KŐsZEGHY P., Utószó, in: RAJNAVÖLGYI 2012, 279-330.

B. MunK OLSEN, Les classiques latins dans les florilèges médiévaux antérieurs au XIIle siècle, in: La Réception de la littérature classique au Moyen Âge (IXe-XIIe siècle), Koppenhága, 1995, 145-273.

G. PARIS, André de France, Romania 1 (1872), 105-107.

G. PARIS, Études sur les romans de la table ronde: Lancelot du Lac: II. Le Conte de la Charette, Romania 12 (1883), 459-534.

G. PARIS, Une traduction d'André le chapelain au 13iéme siècle, Romania 13 (1884), 403-404.

G. PARIS, La littérature française au moyen âge (XIe-XIVe siècle), Párizs, 1888.

B. POSSELT, Hartmann Schedel schreibt Geschichte. Die Entwürfe für die Schedel'sche Weltchronik, in: Franz Fuchs (ed.), Hartmann Schedel (1440-1514): Leben und Werk, Wiesbaden, 2016, 87-124.

P. RAJNA, Tre studi per la storia del libro di Andrea Cappellano, Studi di filologia romanza 5 (1891), 193-272.

F. J. M. RAYNOUARD, Choix des poésis originales des Troubadours, Párizs, 1817.

W. SCHMITT, Bio-bibliographische Bemerkungen zu Hans Hartlieb, in: G. Keil (Hrsg.), Fachprosa-Studien. Beiträge zur mittelalterlichen Wissenschafts- und Geistesgeschichte, 255-271; 584, Berlin, 1982.

B. SCHNELL, Neues zur Biographie Johannes Hartliebs, Zeitschrift für deutsches Altertum und deutsche Literatur 136/4 (2007), 444448.

B. SCHNELL, Hartmann Schedel als praktischer Arzt. Zum medizinischen Alltag im Spätmittelalter oder: die Schwierigkeit, mittelalterliche medizinische Texte zu deuten und zu werten, in: Franz Fuchs (ed.), Hartmann Schedel (1440-1514): Leben und Werk, Wiesbaden, 2016, 75-86.

Th. SundBy (ed.), Albertani Brixiensis Liber Consolationis et Consilii: Ex Quo Hausta Est Fabula Gallica, Koppenhága, 1873.

R. VALENTIN, Verzeichniss der Lateinischen Handschriften der Königlichen Bibliothek zu Berlin, 2, Berlin, 1901.

R. WEISS, Il primo secolo dell'umanesimo. Studi e testi, Roma, 1949.

C. WIENER, Arbeit am Text: Georg Alts und Hartmann Schedels lateinischdeutsche Literaturprojekte, in: Franz Fuchs (ed.), Hartmann Schedel (1440-1514): Leben und Werk, Wiesbaden, 2016, 125-144. 


\section{Amor est passio: Reception of the De amore manuscripts in the $15^{\text {th }}$ century German territories}

The love dissertation De amore was written in the $12^{\text {th }}$ century in a clear French setting, in the courtyard of Marie de Champagne, for a French audience, but also in Latin. The De amore does not appear on German territory in either the $13^{\text {th }}$ or the $14^{\text {th }}$ centuries, but it makes its way there in the $15^{\text {th }}$ century. The presence of the theoretical dissertation can be justified not only in traces, but on the contrary: it is present from the beginning to the end of the century, it occupies a significant place in knightly-didactic poetry. In my study, I present the reception of the treatise in German territories, based on the codices I have examined so far.

Keywords: Andreas Capellanus, De amore, reception, German territories 